\title{
Desmoplastic Fibroma and Cemento Ossifying Fibroma of The Anterior Maxilla: A Rare Case Report
}

\author{
(Desmoplastic Fibroma dan Cemento Ossifying Fibroma: \\ Laporan Kasus Langka) \\ Victor Pakpahan ${ }^{1}$, Eky Nasuri $^{2}$, Vera Julia ${ }^{1}$ \\ ${ }^{1}$ Department Oral and Maxillofacial Surgery, \\ Faculty of Dentistry University of Indonesia, Jakarta, Indonesia \\ Kampus, Jl. Salemba Raya Jl. Salemba Raya IV No.2, RW.5, \\ Kenari, Kec. Senen, Kota Jakarta Pusat, Daerah Khusus Ibukota Jakarta 10430 \\ ${ }^{2}$ Oral and Maxillofacial Surgery Division, Cipto Mangunkusumo National Hospital, Jakarta, Indonesia \\ E-mail: vera.julia@ui.ac.id
}

\begin{abstract}
Tumors located in the maxillofacial part of the body were classified by WHO in 2017 and among these are intraosseous form of fibromatosis known as Desmoplastic and Cemento-ossifying fibromas. These tumors usually occur in the head and neck region, especially in the mandible and are relatively rare in the maxilla. Meanwhile, this study aims to discribe a rare case of the cemento ossifying fibroma that had been previously diagnosed as desmoplastic fibroma with a mass tumor in the anterior of the maxilla. A 22 years old female reported to the Cipto Mangkusumo Hospital with the main complaint of a lump in the right side of the upper jaw which appeared 2 years prior to the operation. In April 2017, the patient had a biopsy in Tarakan Hospital and the result was a desmoplastic fibroma. Due to the lump enlargement, the patient was admitted to RSCM in July 2019 and had biopsy incision with a diagnosis of cemento ossifying fibroma which was confirmed by the histopathological examination and histology report. The resection of the right part of maxilla was conducted alongside with reconstruction using the free fibular flap. Moreover, cemento ossifying fibroma and desmoplastic fibroma shared similar features, namely, clinical, histological and radiological features which are important in establishing the diagnosis and treatment of patient. Hence, extensive enucleation or resection is required due to the progressive nature of the tumor to prevent the potential for further recurrences.
\end{abstract}

Keywords: cemento ossifying fibroma, desmoplastic fibroma, anterior maxilla

\section{Abstrak}

Tumor yang ada di daerah maksilofasial diklasifikasikan oleh WHO pada tahun 2017 termasuk diantaranya lesi yang berasal dari dalam jaringan dan tulang yang dikenal dengan Cemento-ossifying fibroma dan Desmoplastic fibroma .Kedua tumor ini merupakan tumor yang langka terjadi dan biasanya timbul pada regio kepala dan leher terutama pada mandibula tetapi jarang timbul di maksila. Sementara itu, tulisan ini menampilkan kasus yang relatif jarang, yakni kasus cemento ossifying fibroma yang sempat didiagnosis sebagai Desmoplastic Fibroma, dengan massa tumor yang terdapat pada lokasi yang relative jarang terjadi yaitu di anterior maksila Seorang perempuan berusia 22 tahun, datang ke poli Bedah Mulut RSCM dengan keluhan utama benjolan pada rahang atas kanan, dialami sejak 2 tahun yang lalu. Pada April 2017, pasien pernah berobat ke Rumah Sakit Tarakan dan dilakukan biopsi. Hasil biopsi menunjukan benjolan merupakan Desmoplastic Fibroma. Dikarenakan benjolan membesar lagi, pasien lalu berobat lagi ke di RSCM pada bulan Juli 2019 dan dilakukan operasi insisi biopsi dengan hasil Cemento Ossifying Fibroma, pada kesimpulan pemeriksaan patologi anatomi juga didapatkan adalah secara histologi sesuai dengan Cemento Ossifying Fibroma. Dilakukan reseksi pada ranag atas bagian kanan dan rekonstruksi dengan flap dari fibula. Cemento ossifying fibroma dan Desmoplastic Fibroma memiliki beberapa kemiripan. Karakteristik klinis dan radiologis akan membantu menegakkan diagnosis dan pemilihan terapi kepada pasien yang terkena keadaan patologi ini. Enukleasi atau reseksi ekstensif kadang diperlukan karena sifat tumor yang progresif untuk mencegah potensi rekurensi lebih lanjut

Kata Kunci: cemento ossifying fibroma, desmoplastic fibroma, anterior maxilla 


\section{INTRODUCTION}

In early 2017, the updated edition of WHO classification of odontogenic cysts, tumors and maxillafacial bone tumors was published. This includes intraosseous form of fibromatosis, known as Desmoplastic fibroma and Cemento ossifying fibroma. ${ }^{1}$ The cemento ossifying fibroma is a benign fibroosseous neoplasm which consists of abnormal bone cells and cementum in fibrous connective tissue. ${ }^{2}$ Furthermore, the cemento ossifying fibroma has three development stages. In the early stage of osteolytic, the tumors consist of only cellular tissue with no calcification material ${ }^{3}$ and the radiographic images show immature cementum that appears radiolucent. ${ }^{4}$ Moreover, in the cementoblastic stage, the cementum are calcified and embedded to the fibrous mass and showed a radiopaque image. ${ }^{4}$ At the final or mature inactive stage, all mass is calcified and encapsulated. ${ }^{5}$

Cemento ossifying fibroma often shows varia-tion in clinical, radiographic and histopathological characteristics. ${ }^{6}$ Most of these lesions are slow-growing and are only identified once the lesion causes swellling in the face, ${ }^{6}$ however, some cases grow rapidly and show symptoms in patients. ${ }^{7}$ Meanwhile, inadequate surgical treatment leads to recurrence, therefore, proper diagnosis and treatment plan is essential to achieve an excellent result. ${ }^{8}$ Clinically, the benign tumors are round, encapsulated, slow-growing, expansive, and rarely show signs of ulceration and bleeding while, the tumors are well-differentiated microscopically and cause no metastases. ${ }^{9}$

Desmoplastic Fibroma is a rare benign tumor that originates from connective tissue and locally aggressive without being metastasize. ${ }^{10}$ The location of the tumor in the jaw was first stated by Griffith and Irby (1965). ${ }^{11}$ Desmoplastic fibroma has a histological feature similar to soft tissue tumors. ${ }^{12}$ Clinically, these tumors are often located in the posterior side of the mandible with slow growth and absence of pain. ${ }^{13}$ Meanwhile, clinical and radiographic features often show clear signs of an existing desmoplastic fibroma, however, a histopathological examination is required to determine a definite diagnosis. ${ }^{12,13}$

This study describes a rare case report of cemento ossifying fibroma that had been previously diagnosed as desmoplastic fibroma with a tumor mass located in the anterior of the maxilla which is a relatively rare location. The patient was treated with resection followed by reconstruction using a free fibular flap (FFF).

\section{CASE}

A 22 years old female reported to the Specialist Clinic of Oral and Maxillofacial Surgery, Cipto Mangkusumo Hospital (RSCM) with the main complaint of a lump in the right side of the upper jaw that appeared 2 years prior to the operation. The lump enlarged in size in the last 2 months without existing pain, fever or drastic weight loss.

There is no history of trauma or discharge of the swelling from inside or outside the mouth. However, the patient complained of nasal congestion on the right side of the nose, especially in the supine position.

During extraoral examination, the lump in the right maxilla region was visible and extended from the right corner of the nose to the right cheek area with a size of approximately $8 \times 7 \times 4 \mathrm{~cm}$ which appeared to have a hard consistency, well-demarcated, fixated, smooth surface, no tenderness on pressure test and color, and the temperature was the same as its surrounding. Furthermore, there was no detectable blood and pus drainage from the lump while the pingpong ball phenomenon was absent.

Meanwhile, during the intraoral examination, the lump in the right buccal vestibule extended to the gingiva region of tooth 12 to tooth 16 . The lump size was $5 \times 3 \times 2 \mathrm{~cm}$ in size which have hard consistency with a smooth surface, fixated, no tenderness upon pressure test, while the temperature and color of its surrounding were the same. In addition, there was no detectable blood and pus drainage from the lump.

The results of the Panoramic radiograph and $\mathrm{Si}$ nus/orbital/facial contrast CT scan showed signs of an expansive bone tumor with extensive calcification with destruction in parts of the processus alveolaris cortex and right maxillary sinus, filling the maxillary sinus, cavum nasi and right ethmoid sinus with left maxillary sinusitis.

In April 2017, the patient went to Tarakan Hospital and had biopsy examination and extraction of the loose upper right tooth and the results showed that the lump was a Desmoplastic fibroma. When the lump showed signs of enlargement 2 years after the biopsy was conducted, the patient went to RSCM in July 2019 and had biopsy. Meanwhile, the histopathology examination result of the biopsy was cemento ossifying fibroma.

\section{CASE MANAGEMENT}

After receiving the patient consent, resection of the right part of maxilla up to region 16 was carried out 
alongside with reconstruction using the free fibular flap (FFF). The patient was later scheduled for evaluation and postoperative follow up.

\section{DISCUSSION}

This study is based on the WHO classification of odontogenic cysts, tumors and maxillofacial bone tumors that was published in early 2017. Among these tumors are intraosseous form of fibromatosis known as desmoplastic fibroma and cemento-ossifying fibroma. ${ }^{11,15}$ Although there are persistent variations in the classification and diagnosis of lesions in the craniofacial bones, there is consensus on the common characteristics of these lesions. However, all the lesions show the replacement of normal bone tissue by fibroblast and collagen fiber tissue with different amounts of mineralized substances. ${ }^{16}$

Griffith and Irby in 1965 reported the first case of jaw bone desmoplastic fibroma that occurred in the mandible of an 8 year old girl. ${ }^{17}$ Moreover, the desmoplastic fibroma lesions are usually painless, slowgrowing and asymptomatic swellings. ${ }^{12,18}$ Furthermore, facial asymmetry, tooth displacement, root divergence, pain, trismus and infections are other symptoms. ${ }^{19}$ Meanwhile, from the radiology examination of desmoplastic fibroma affecting the jaws, the result showed similar features with other lesions. ${ }^{10,19}$ Similarly, the age range and radiologic results of cases were insignificantly different from those stated in previous studies.

Based on this study, the desmoplastic fibroma was located in anterior maxilla. Meanwhile, Woods et al. in 2015, evaluated 152 gnathic desmoplastic fibromas and stated that the tendency to occur in women is $56 \%$ greater, with most cases under the age of 30 while the location in mandibular posterior was favored by $84 \% .{ }^{17}$ However, when Evans HL in 1995 , described the desmoplasticic fibroma, only ten cases (PubMed and LILACS) were reported within the oral cavity due to the tumor effects on mainly soft tissue while the intraosseous manifestations as described in this study are rare ${ }^{20}$ Meanwhile, among the ten cases of desmoplastic fibroma of the oral cavity, only one described by Jaafari-Ashkavandi $Z$ et al., was intraosseous and located in the maxillary alveolar bone. ${ }^{21}$ Hence, this study is an extremely rare case where the lesion occurred in oral cavity and anterior of the maxilla

The histology of desmoplastic fibroma is the presence of a hypocellular stroma that contains numerous collagen with clusters of fibroblasts. ${ }^{11}$ Meanwhile, the result of histopathological examination confirms the definitive diagnosis.
Saranya et al. stated that desmoplastic fibroma progresses to bone destruction which tends to invade the soft tissues while untreated and inadequate treatment has a high propensity for local recurrence. ${ }^{10,22}$ In the case of this study, when the first biopsy showed desmoplastic fibroma, adequate treatment was not followed immediately. According to the patient, extraction of the anterior teeth which was felt mobile due to the pressure of the lump was carried out. Meanwhile, when the size of the tumor was felt larger after 2 years, the patient went to RSCM in July 2019 and had biopsy. The result of the histopathology examination of biopsy was cemento ossifying fibroma.

Barner's hypothesis stated that cemento ossifying fibroma are caused by irritation and trauma (e.g., tooth extraction). Meanwhile, the trauma activates the production of new periodontal membrane tissues that adhere to alveolar wall and develop as cemento ossifying fibroma. Furthermore, this hypothesis as stated in a study by Andrade et al., supported this study, where the patient extracted the maxillary right teeth 2 years prior to the operation..$^{23}$ The extraction was carried out during biopsy incision procedure at Tarakan Hospital in 2017.

The histopathological results of cemento ossifying fibroma are mostly rich and poor cells which adhere to the undefined bone. ${ }^{24}$ Meanwhile, the pathological result of the patient's first biopsy was desmoplastic fibroma while the second was cemento ossifying fibroma. The difference in pathological result of the two biopsies are due to inadequate management of the desmoplastic fibroma and the extraction of anterior teeth. Hence, further study is required to support these results.

Cemento ossifying fibroma is categorized as a benign fibroosseous tumor that is slow-growing and painless while facial asymmetry and tooth displacement were observed in some cases. ${ }^{2,24}$ Meanwhile, this evidence supported the result where the patient also exhibited slow-growing tumor without any complaint of pain.

Moreover, Grewal et al. stated that cemento ossifying fibroma was rare in the maxilla and $62 \%$ to $89 \%$ of all the cases were reported in the mandible where $77 \%$ of the patients had cemento ossifying fibroma in the premolar. ${ }^{2}$ The cemento ossifying fibroma in this study is in the maxillary anterior region which had been previously reported as a rare location for this lesion.

The radiographic image of cemento ossifying fibroma shows a sign for jaw destruction and unilocular radiolucency in the early stage of lesion formation. ${ }^{25}$ Meanwhile, this evidence supported the case study 
where the panoramic image showed a radiolucency of the right maxillary bone.

The treatment of cemento ossifying fibroma and desmoplastic fibroma depends on clinical, radiographic and histopathologic results of the bone destruction activity. Furthermore, the cemento ossifying fibroma and desmoplastic fibroma treatment includes surgical enucleation and primary closure for smaller lesions as well as local excision/curettage for moderately larger lesions. ${ }^{5,14}$

Kaur et al. stated that curettage is carried out to completely enucleate the smaller lesions with no cleavage margin while more radical approaches are indicated for larger cemento ossifying fibroma to lower the risk of recurrence caused by the incomplete removal of the lesion. Depending on the size and volume of bone destruction, monobloc resection are carried out alongside with bone reconstruction using iliac crest non-vascularized bone graft or free fibula flap. ${ }^{8,26}$ Meanwhile, in cemento ossfying fibroma recurrent cases where the lesion growth interferes with significant anatomical structures, more aggressive surgical procedures are indicated. In this study, complete enucleation or extensive resection was carried out considering the tumor progression and possibility of further recurrences alongside with maxillary resection and reconstruction with a free fibular flap conducted by plastic surgeon.
Hence, the clinical and radiographic assessment are carried out to determine the diagnosis of cemento ossifying fibroma and desmoplastic fibroma while the histopathological examination helps in definitive diagnosis confirmation. Considering the lesion growth nature, treatments are different from one case to another. Meanwhile, complete enucleation and extensive resection are carried out when the lesion growth interferes with significant anatomical structures, recurrent cemento ossifying fibroma and desmoplasticic fibroma cases. However, to prevent lesion progression or future recurrences, more aggressive surgical procedures are recommended.

\section{ACKNOWLEDGEMENTS}

The author is grateful to the Oral and Maxillofacial Surgery Division, Cipto Mangkusumo National Hospital (RSCM) for the invaluable assistance provided in this study.

\section{CONFLICT OF INTEREST}

The authors declared that there is no conflict of interest in this study.

\section{TABLES}

Table 1. Suarez et al described differential diagnosis between Cemento Ossyfying Fibroma and Desmoplastic Fibroma. ${ }^{14}$

\begin{tabular}{|c|c|c|}
\hline & $\begin{array}{l}\text { Cemento } \\
\text { Ossifying } \\
\text { Fibroma }\end{array}$ & $\begin{array}{l}\text { Desmoplastic } \\
\text { Fibrona }\end{array}$ \\
\hline Age & $3^{\text {rd }}-4^{\text {th }}$ decade & $1^{\text {st }}$ decade \\
\hline Gender & $>$ Female & No difference \\
\hline Location & Posterior jaw & Posterior jaw \\
\hline Clinical Symptoms & $\begin{array}{ll}- & \text { Deformity Swelling } \\
- & \text { Displacement or tooth } \\
\text { mobility }\end{array}$ & $\begin{array}{ll}- & \text { Deformity Swelling } \\
- & \text { Displacement or tooth mobility }\end{array}$ \\
\hline & - Well defined & - Well defined \\
\hline X-Ray & $\begin{array}{ll}\text { - } & \text { Radiolucent } \\
\text { - } & \text { Unilocular or multilocular }\end{array}$ & $\begin{array}{ll}\text { - } & \text { Radiolucent } \\
\text { - } & \text { Unilocular or multilocular }\end{array}$ \\
\hline Histology & $\begin{array}{l}\text { Fibrous stroma cell variability } \\
\text { and trabecular calcified foci } \\
\text { (bone) / spheroid (cement) }\end{array}$ & $\begin{array}{c}\text { Rich in collagen stroma and fibroblast } \\
\text { group }\end{array}$ \\
\hline Treatment & $\begin{array}{l}\text { Currettage and bone } \\
\text { remodeling }\end{array}$ & $\begin{array}{l}\text { - Remodeled and curettage (if cortial } \\
\text { bone not affected) }\end{array}$ \\
\hline & - Resection & $-\quad$ Resection \\
\hline Recurrence Rate & $\begin{array}{l}\text { Rare recurrence }(0-20 \%) \text { even } \\
\text { with curettage treatment }\end{array}$ & $\begin{array}{c}\text { A high rate of recurrence (incomplete } \\
\text { curettage) }\end{array}$ \\
\hline
\end{tabular}




\section{FIGURES}

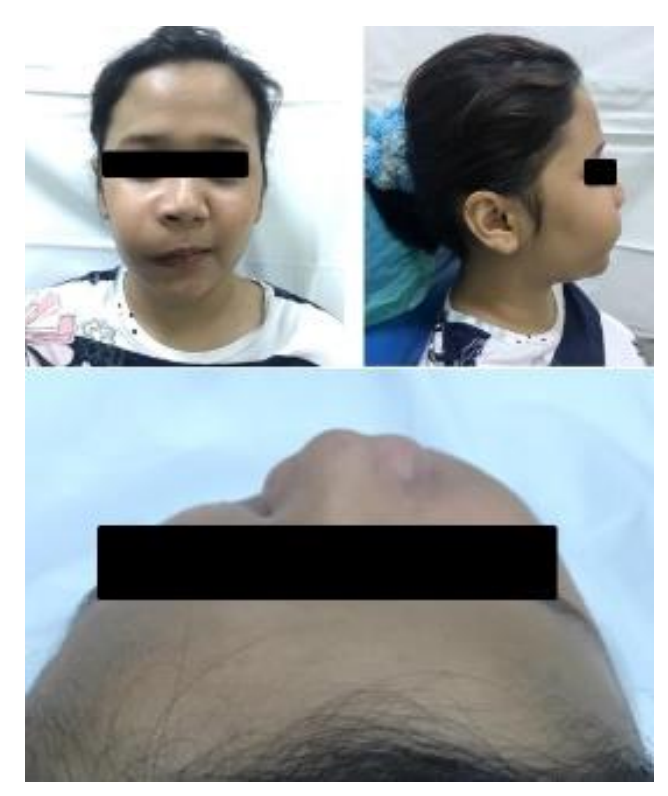

Fig 1. Extra-oral clinical photo, swelling on the right side of the face

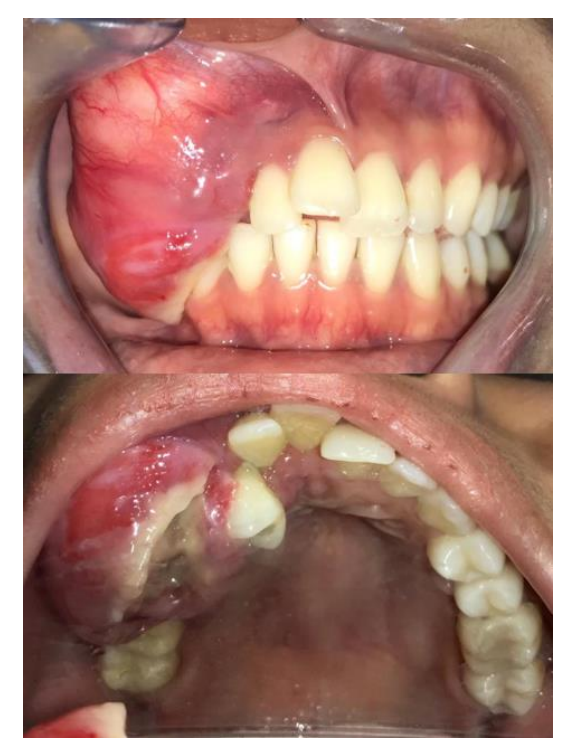

Fig 2. Preoperative intraoral clinical photo, a swelling on the labial and buccal-side. 


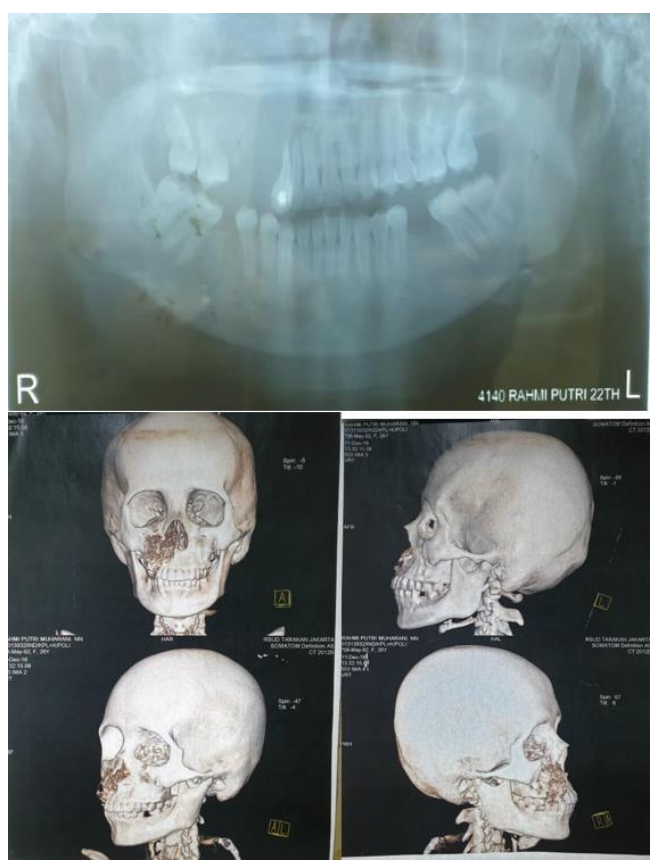

Fig 3. Panoramic radiograph and contrast CT Scan result of the sinus/orbital/facial

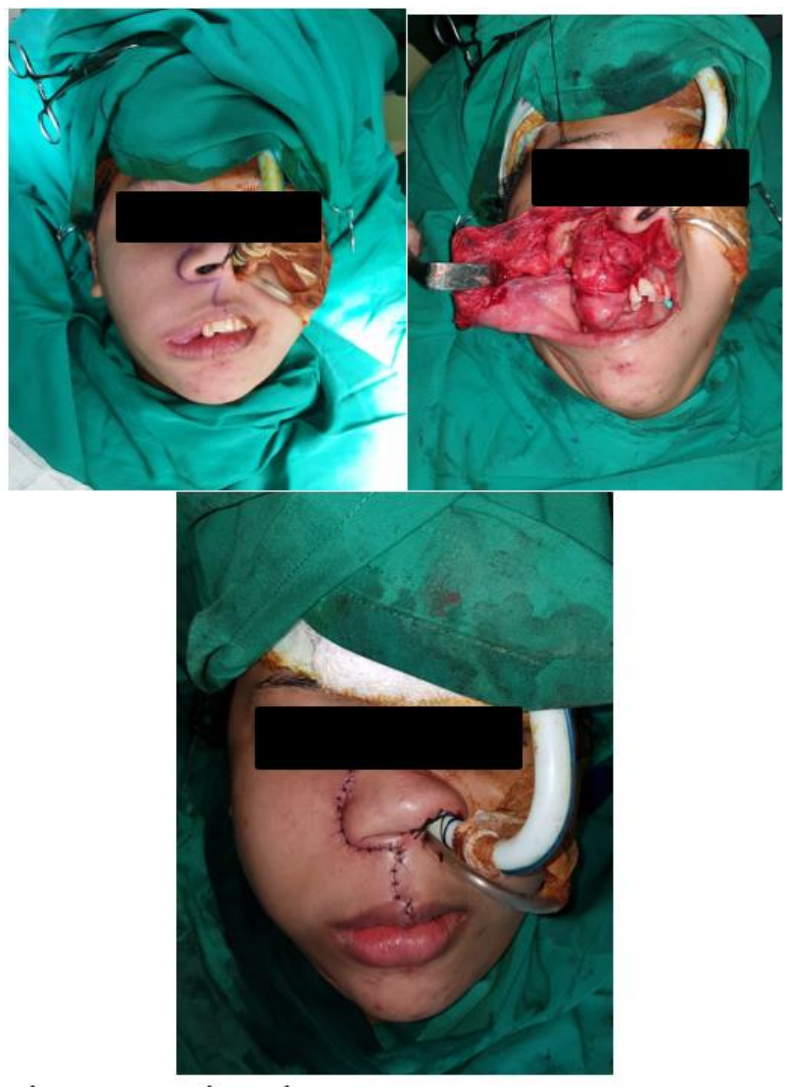

Fig.4. Operation Photo 


\section{REFERENCES}

1. Wright JM, Vered M. Update from the 4th Edition of the World Health Organization Classification of Head and Neck Tumours: Odontogenic and Ma-xillofacial Bone Tumors. Head Neck Pathol 2017; 11(1): 68-77.

2. Grewal M, Gautam S, Tanwar R, Saini N. Ce-mentoossifying fibroma of maxilla: An unusual case report. J Dent Res Rev 2020; 7(4): 206.

3. Olgac V, Sinanoglu A, Selvi F, Soluk-Tekkesin M. A clinicopathologic analysis of 135 cases of cementoosseous dysplasia: To operate or not to operate? J Stomatol Oral Maxillofac Surg 2020; 122(3): 278-82

4. Aburas S, Bandura P, Al- Ibraheem A, Berger S, Meier M, Turhani D. A large maxillary cementoossifying fibroma superimposed with solitary bone cyst documented over 18 years: A case re-port. Int J Surg Case Rep 2020; 68: 257-62.

5. Mainville GN, Turgeon DP, Kauzman A. Diag-nosis and management of benign fibro-osseous lesions of the jaws: a current review for the dental clinician. Oral Dis. 2017; 23(4): 440-50.

6. Wanzeler AMV, Rohden D, Arús NA, Silveira HLD, Hildebrand LC. Central Cemento-Ossifying Fibroma: Clinical Imaging and Histo-pathological Diagnosis. Int J Odontostomatol 2018; 12(3): 233-6.

7. Rani A, Kalra N, Poswal R, Sharma S. Cementoossifying fibroma: Report of a case and emphasis on its diagnosis. Indian Js Multidiscip Dent 2017; 7(2): 140.

8. Kaur T, Dhawan A, Bhullar RS, Gupta S. CementoOssifying Fibroma in Maxillofacial Re-gion: A Series of 16 Cases. J Maxillofac Oral Surg 2021; 20(2): 2405

9. Patait M, Chaudhari V, Mathew A, Mangrolia R, Ahire M. Cemento-ossifying fibroma: Case re-port. Int. J Appl. Dent. Sci 2020; 6(4): 215-8

10. Konikoth S, Bose T, Anupama IV, Yogidas R. Desmoplastic Fibroma of the Mandible - A Rare Benign Tumor Mimicking Malignancy. J Indian Acad Oral Med Radiol. 2019; 31(1): 74-8.

11. Madakshira MG, Bal A, Verma RK. Desmo-plastic fibroma of the mandible: a rare gnathic bone tumor with a review of the literature. Autops Case Reports 2019; 9(4): e2019091

12. Karimi A, Derakhshan S, Khiavi M, Mosavat F, Mirjalili F. Desmoplastic fibroma of the jaws: A case series and review of literature. Iran J Pathol 2020; 15(2):134-43.

13. Kahraman D, Karakoyunlu B, Karagece U, Ertas U, Gunhan O. Desmoplastic fibroma of the jaw bones: A series of twenty-two cases. J Bone Oncol 2021; 26: 100333.
14. Suarez-Soto A, Baquero-Ruiz de la Hermosa MC, Minguez-Martínez I, et al. Management of fibroosseous lesions of the craniofacial area. Pre-sentation of 19 cases and review of the literature. Med Oral Patol Oral Cir Bucal 2013; 18(3): 479-85

15. Singh AK, Kumar N, Singh S, Pandey A, Verma V. Juvenile ossifying fibroma of the mandible: A case report and review. J Dent Allied Sci 2018; 7(1): 34-7

16. Nelson BL, Phillips BJ. Benign Fibro-Osseous Lesions of the Head and Neck. Head Neck Pathol 2019; 13(3): 466-75.

17. Khatib B, Pogrel MA. Desmoplastic fibroma of the mandible in young children - a case series. Int J Oral Maxillofac Surg 2017; 46(2): 173-80.

18. Kendi TK, Erakar A, Saglik Y, Yildiz HY, Erekul S. Desmoplastic fibroma of bone: A case report. Clin Imaging 2003; 27(3): 200-2.

19. Fahmy MD, Gupta A, Padilla RJ, Segura A, Brookes CD. Desmoplastic fibroma associated with tuberous sclerosis: case report and literature review. Oral Surg Oral Med Oral Pathol Oral Radiol 2019; 128(2): 92-9.

20. Garcia NG, De Freitas Filho SAJ, Soares CT, Figueiredo CM, Oliveira DT. Intraosseous collagenous fibroma (Desmoplastic fibroblastoma) involving maxillary bone. J Clin Diagnostic Res. 2018; 12(2): 6-8.

21. Jaafari-Ashkavandi Z, Yasamin Shirazi M, Assar S. Desmoplastic fibroblastoma in maxillary alve-olar bone mimicking an odontogenic lesion: A no-vel case report with review of literature. Turk Pa-toloji Derg 2018; 34(3): 247-50.

22. Mohammadi F, Shirani G, Derakhshan S, Faghihi T. Desmoplastic fibroma of the lower jaw in a 2-year-old patient; Report of a rare case. Dent Res J (Isfahan) 2020;17(3): 231-4.

23. Andrade NN, Choradia S, Aggrawal N, Mathai PC. Unusual Location and size of a Craniofacial Ossifying Fibroma - A Rare Case Report. Clin Dent. 2018; 12(4): 26-9.

24. Miyashita H, Suzuki H, Matsui K, et al. Pediatric cemento-ossifying fibroma of the anterior mandible: A case report. J Oral Maxillofac Surgery, Med Pathol 2020; 32(4): 285-90.

25. Srivastava P, Sawhney A, Agarwal S, Rathi VC, Dhar S. An unusual association of cemento-ossifying fibroma with an odontoma in mandible : a case report. 2020;1:22-24.

26. Unal A, Kum NY, Kum RO, et al. Giant cementoossifying fibroma of the maxilla. Tumori 2015; 101(6): 163-6. 